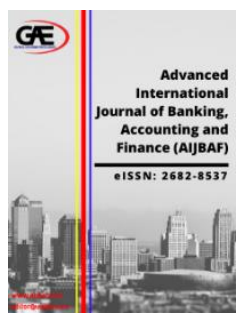

\author{
Advanced International Journal of Banking, \\ Accounting and Finance (AIJBAF) \\ Journal Website: http://aijbaf.com/ \\ eISSN: 2682-8537
}

\title{
VALUATION BUSINESS IN PEER TO PEER LENDING WITH DISCOUNTED CASH FLOW (DCF) METHOD
}

\author{
Muhammad Akhirul Hakim ${ }^{*}$, Dr. Raden Aswin Rahadi, RFA ${ }^{2}$, M. Akmal Adrianza S.E., M. Ak., \\ $\mathrm{ACPA}^{3}$ \\ 1 School of Business Management, Institut Teknologi Bandung, Indonesia \\ Email: muhammad_hakim@sbm-itb.ac.id \\ 2 School of Business Management, Institut Teknologi Bandung, Indonesia \\ Email: aswin.rahadi@sbm-itb.ac.id \\ 3 PT ABC, Jakarta \\ Email: akmalonwork@gmail.com \\ * Corresponding Author
}

\section{Article Info:}

Article history:

Received date:08.04.2020

Revised date: 20.04 .2020

Accepted date: 26.04 .2020

Published date: 10.06 .2020

\section{To cite this document:}

Hakim, M. A., Rahadi, R. A., \& Adrianza, M. A. (2020). Valuation Business in Peer to Peer Lending with Discounted Cash Flow (DCF) Method. Advanced International Journal of Banking, Accounting, and Finance, 2 (3), 01-12.

DOI: $10.35631 /$ AIJBAF.23001.

\begin{abstract}
:
Start-up companies are businesses that are now very popular in Indonesia. To support the business moving fast, these businesses need investors by offering the company's fair value. With similar but not the same calculation, in which start-up companies have different financial indicators and financial assumptions with conventional companies, in this case, the valuation is included innovation value and disruption probability. This research is a descriptive study which is based on case studies in the research object. The object of research is PT ABC, a company engaged in the field of Financial Technology. Data collection is done by collecting secondary data from the company and observation during the internship. The analysis is done by conducting a sensitivity analysis with the DCF method using Microsoft Excel. Valuation is also very closely related to Financial Projection to predict the state of the industry pear to pear landing in the future. The data shows that the enterprise value is Rp. 46,084,735,403,742. Then, EV/Revenue is 1,748 times, and the percentage of raise is $100 \%$. According to DCF Valuation, the author suggests investors invest in the company. Because the valuation is very good.
\end{abstract}

Keywords:

Start-up Valuation, Fintech, Discounted Cash Flow (DCF), Financial Projection, Innovation Value, Disruption Probability, and Sensitivity Analysis

\section{Introduction}

A startup is a company initiated by a founder or individual entrepreneur to look for repeatable and measurable business models. The founders designed the startup to effectively develop and validate a scalable business model (Robehmed, 2013). The startup is a very popular business in Indonesia. Proven in 2018, Indonesia's creative economy agency recorded 992 start-ups in 
Indonesia. Therefore, funding is very important to develop business in startups, so startups in Indonesia are looking for investors who want to invest their funds. So, company valuation is needed as a basis for investors to invest in a start-up company which is a plan or carry out a company action.

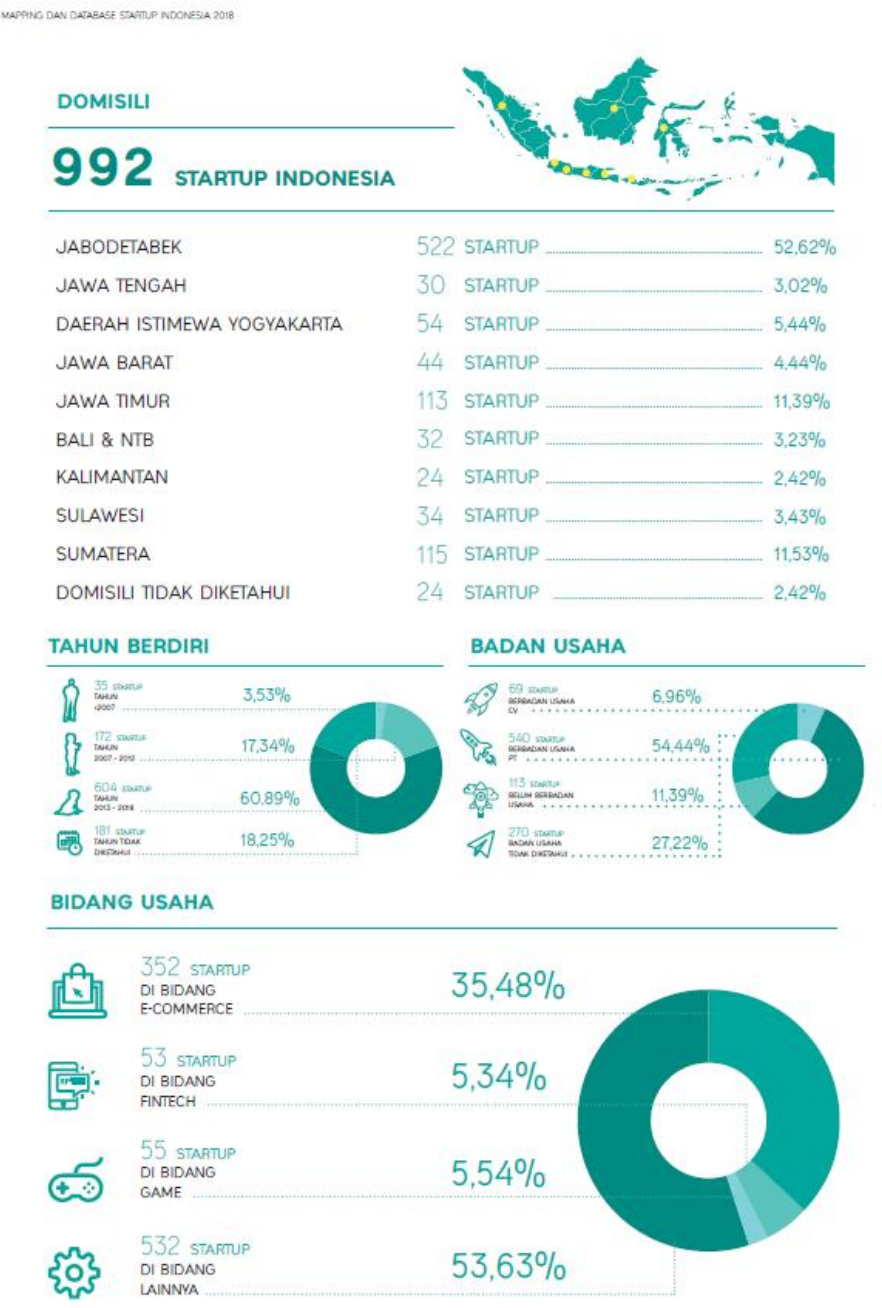

(Zaky, 2018)

Figure I. Domicile of Indonesia Start-up

The importance of valuation is set based on IFRS 13 about fair value measurement. With the device, it is hoped that start-ups in Indonesia can do their company valuations appropriately to receive funding from investors to support the speed of business development.

PT ABC is a start-up company in the field of fintech. The company has the vision to bring happiness into life. The company ensures that all stakeholder components, from farmers to consumers, can be happy because of the company. Our efforts to make this happen are by applying technology, empowering local communities, increasing labors' income, creating new entrepreneurs in rural areas, and collaborating with others. (PT ABCs' Company Profile)

\section{Business Issue}

PT ABC conducts its business to obtain income in 2 ways, 1.) by opening investment projects. 2) manage the capital that has been invested to get a return to each party. The company has 
successfully carried out 112 projects, employs 1,900 labors, owns 500 hectares of land, and 35,000 supplies.

This company is facing funding problems in its business operations so that it runs smoothly due to cashflow turnover that is so fast. The company's valuation is needed so that the company gets funding from outside the business, then investors can decide to invest in this company. Venture capital provides equity financing for small businesses and is often risky in return for a share of company ownership (Damodaran, 2011). In another opinion says that investors as providers of funds need to assess the due diligence of the companies they will invest. Also, investors expect a profitable product and an attractive ratio of income to equity, which makes management have to manage the source of the surplus successfully and sustainably (Pohl, 2017)

The author chooses the DCF method as company valuation and compares it with similar businesses. Then do a sensitivity analysis on the feasibility of investing in this company. Company valuation plays an important role in determining the proportion of equity maintained by founders and investors, as well as determining the basis for future fundraising if needed (Bell, 2014).

\section{Literature Review}

\section{Start-up Company}

The start-up companies are temporary organizations or partners formed to find business models regularly and measured (Blank, 2012). The origin of start-up companies in the field of technology then develops in other fields such as new investment services and funding which we call financial technology or fintech (Robehmed, 2013).

The start-up is a human institution design that creates something new under extreme conditions and serenity. It doesn't say about what size of the company or what sector of the industry, it just says we're trying to do institution-building when we don't know what we don't know (Ries, 2011).

The term start-up describes a company in the early stage of the business lifecycle with a high degree of innovation looking for capital resources. The difference to other companies in their early stage is the level of innovation and outstanding growth potential (Achleitner, 2018).

Based on the opinions above, the author concludes that Start-up is a digital-based start-up business that aims to provide existing social solutions to the community and has a rapid business development on funding from investors who invest their funds in the start-up itself.

\section{Business Valuation}

Company valuation is commonly used to determine the precise value of one company at a time. One of the reasons why companies assess their value is because of the requirement from impending investors or the investor to do the valuation by themselves or to maximize the company's value and estimating the effects of various alternative strategies (Brigham, 2004).

A valuation is a process of determining the fair market value of a company in a national context, meaning that the valuation is a) time-specific, b) there is no negotiation, and c) there is no exposure to the open market (Divestopedia, 2016). 


\section{Discounted Cash Flow Valuation}

The importance of using cash flows in valuation is stressed where analysts ranked free cash flow and operating cash flow as number one and two respectively when ranking accounting variables in order of importance (Imam, 2008). Discounted Cash Flow models measure the intrinsic value of a company and are based on the rationale that the current value of an asset is equal to the present value of all expected future cash flows (Lopez, 2008). Discounted cash flow valuation estimates the value of any asset by discounting the expected cash flow on that asset at the rate that reflects their riskiness (Damodaran, 2011). The only path that will be used is to value the entire firm, including equity and any other claims in the firm (from bondholders, preferred stockholders, etc). There are three major variables functioned by the value of the company: the expected net cash flows, the expected growth of the cash flows, and the required rate of return (Ivanovska, 2014). The value of the firm is obtained by discounting expected cash flow to the firm at the weighted average cost of capital. The formula of the calculation showed below (Curry, 2018):

$$
\begin{aligned}
& \qquad \begin{array}{l}
\text { DCF Formula }=\frac{C F_{1}}{(1+r)^{1}}+\frac{C F_{2}}{(1+r)^{2}}+\frac{C F_{3}}{(1+r)^{3}} \ldots+\frac{C F_{n}}{(1+r)^{n}} \\
\text { Explanation: } \\
C F_{1} \quad=\text { Cash Flow year } 1 \\
\mathrm{n} \quad=\text { year } \mathrm{n} \\
\mathrm{r} \quad=\text { Discounted Rate }
\end{array}
\end{aligned}
$$

All of the respondents which consisted of investment banks in the US used DCF as the standard to evaluate a company, even though they think that this method is not suitable in every situation (Brotherson, 2014).

4 elements are calculating fair value, i.e. cash flow from existing assets, estimated growth rate, discount rate, terminal value. The four stages in the assessment of startup companies include (Samonas, 2015):

Stages 1: estimate cash flow in year 5 in the future. The period is adjusted by the company's management and predicted with free cash flow growth average obtained geometrically using the following formula.

$$
\text { Geometric mean }=\left[\frac{\text { Earning }_{0}}{\text { Earnings }_{-n}}\right]^{\frac{1}{n}}-1
$$

Where:

$-n=$ revenue in year $n$ for the last year

Stage 2: The discount rate (return) can be calculated using the Weight Average Cost of Capital (WACC). Calculated WACC, we need to know the beta, To use this approach, the beta of comparable companies is taken from Bloomberg and the unlevered beta for each company is calculated (Corporate Finance Institute, 2020)

$$
\text { Unlevered Beta }=\text { Levered Beta / }((1+(1-\text { Tax Rate }) *(\text { Debt } / \text { Equity }))
$$

The average of the unlevered betas is then calculated and re-levered based on the capital structure of the company that is being valued (Corporate Finance Institute, 2020)

$$
\text { Levered Beta }=\text { Unlevered Beta * }((1+(1-\text { Tax Rate }) *(\text { Debt } / \text { Equity }))
$$


After we get the beta, we can calculate the WACC, Discounted rate or Cost of Capital can be calculated using the weighted average or can be called the Weighted Average Cost of Capital (WACC) (Djaja, 2017). The WACC formula is:

$$
W A C C=\frac{E}{V} K_{e}+\frac{P}{V} K_{p s}+\left(\left(\frac{D}{V} K_{d}\right) x(1-t)\right)
$$

Where:

$\mathrm{E}=$ market value of the firm's equity (market cap)

$\mathrm{D}=$ market value of the firm's debt

$\mathrm{P}=$ market value of the firm's preferred stock

$\mathrm{V}=$ total value of capital (equity plus debt)

$\mathrm{E} / \mathrm{V}=$ percentage of capital that is equity

$\mathrm{D} / \mathrm{V}=$ percentage of capital that is debt

$\mathrm{P} / \mathrm{V}=$ percentage of capital that is preferred stock

$\mathrm{Ke}=$ cost of equity (required rate of return)

$\mathrm{Kd}=$ cost of debt (yield to maturity on existing debt)

$\mathrm{Kps}=$ cost of preferred stock

$\mathrm{T}=$ tax rate

Stage 3: The cash flow assessment at the end of the forecast period can be sought by calculating the terminal value. There are various approaches to calculating the terminal value. Amongst the most common approaches are (Samonas, 2015):

- Exit Multiples, Where the terminal value is calculated using comparable company multiple like EBITDA or EBIT (e.g. the terminal value of the company should be worth 5 times its EBITDA)

Stage 4: To calculate the sensitivity analysis, we can use the NPV formula. The NPV formula is used to determine the present value of the project by (Samonas, 2015):

$$
N P V=-C f_{0}+\sum_{i=1}^{T} \frac{C f_{i}}{(1+r)^{i}}
$$

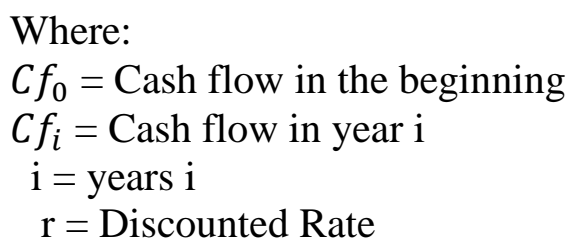

\section{Research Methodology}

The research is a case study research with the descriptive method in a start-up company (PT ABC) in December 2019 - March 2020. Aims to describe what currently applies. There is an attempt to describe, record, analyze, and interpret the conditions that currently occur or exist (Mardalis, 2010). In other words, descriptive research aims to obtain information about the current situation and see the relationship between the variables that exist. This study does not test hypotheses or does not use hypotheses, but only describes information as it is following the variables studied. Data collected through descriptive research one of which serves to Copyright (C) GLOBAL ACADEMIC EXCELLENCE (M) SDN BHD - All rights reserved 
provide an understanding of the characteristics of a group in certain situations (Sekaran, 2010). The analysis is done by conducting a sensitivity analysis with the DCF method using Microsoft Excel with flexibility assumption as advantageous or disadvantageous based on google analytics. Therefore, this approach is very commonly used to assess early-stage technology companies (Blake, 2016).

\section{Study Analysis}

\section{Assumption of Revenue}

The assumption of Revenue is using the data from google analytics. The author chooses the order data from PT ABC's customer's annual visit then forecasting the target growth with geometric mean then accepted by management. The target growth is more or less $20 \%$ in the next five years. After forecasting the growth, author, and management breakdown with conversion rate as a result of the ordered costumer. The conversion rate is the percentage of visitors who order the goods/service from digital businesses.

Table 1: Assumption of Revenue

\begin{tabular}{|c|c|c|c|c|c|c|c|}
\hline & $\begin{array}{l}\text { Start- } \\
\text { up }\end{array}$ & & & & & & $\begin{array}{r}\text { Termina } \\
1 \text { year }\end{array}$ \\
\hline & $\begin{array}{r}\text { year } \\
2019\end{array}$ & 2020 & 2021 & 2022 & 2023 & 2024 & 2025 \\
\hline
\end{tabular}

Site Traffic (Avg monthly visits)

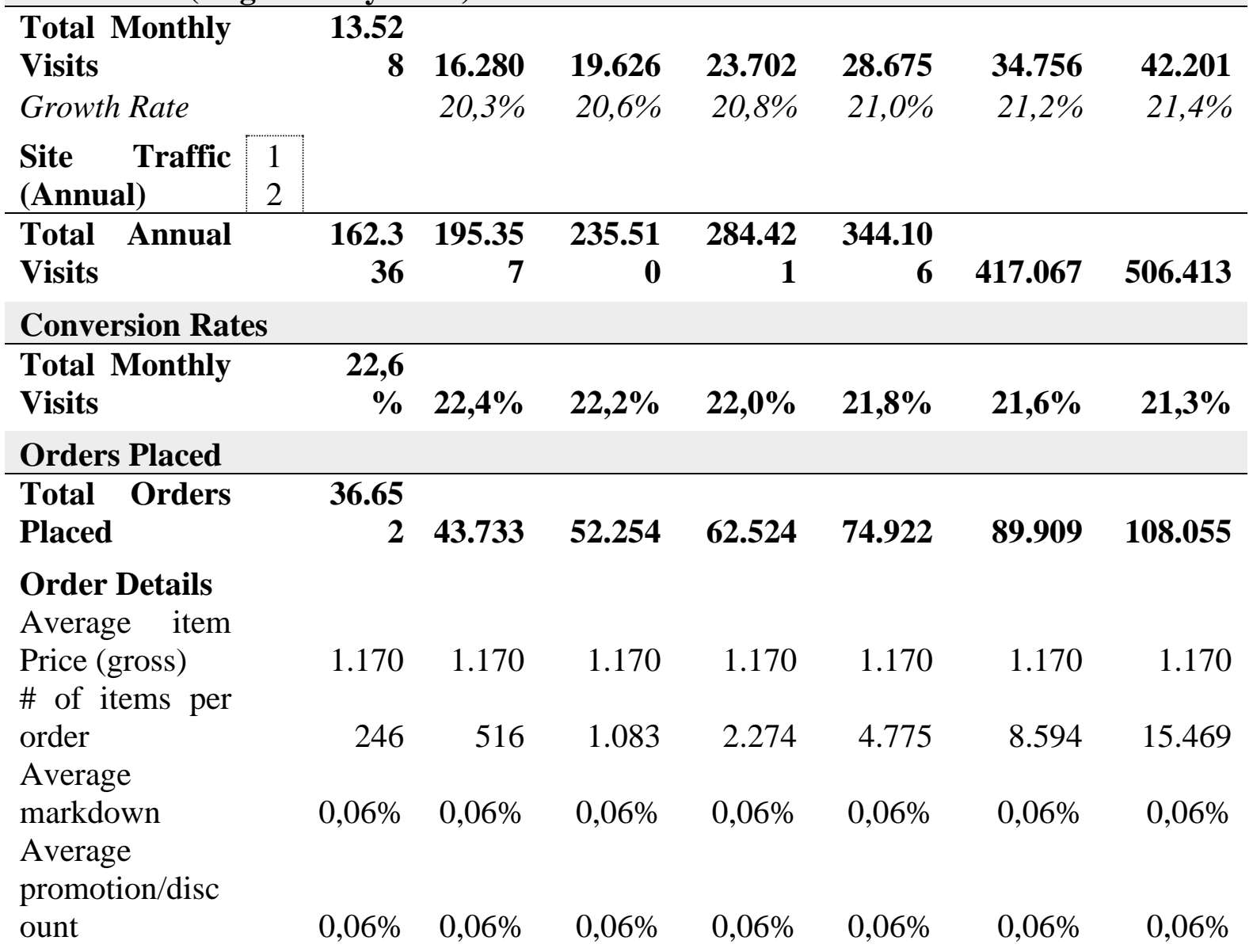


Cost of Return

(Gross return of investment)

Average Gross

order value

Average Net

order value

$\begin{array}{rrrrrrr}0 \% & 0 \% & 0 \% & 0 \% & 0 \% & 0 \% & 0 \% \\ 287.1 & 603.01 & 1.266 .3 & 2.659 .3 & 5.584 .5 & 10.052 .1 & 18.093 .9 \\ 51 & 7 & 36 & 05 & 41 & 74 & 14 \\ 286.8 & 602.32 & 1.264 .8 & 2.656 .2 & 5.578 .1 & 10.040 .6 & 18.073 .1 \\ 21 & 4 & 81 & 51 & 26 & 27 & 29\end{array}$

Customers

Churn Rate

$26 \%$

$26 \%$

$26 \%$

$26 \%$

$26 \%$

$26 \%$

$26 \%$

Opening an

active customer

base

\section{0}

27.057

52.259

77.154

103.11

Plus new 36.65

customers

36.65

Subtotal

Less churned

customers

Closing the

customer base

27.05

$2 \quad 43.733 \quad 52.254$

62524

$4 \quad 131.430 \quad 163.398$ 9

(1)

(Author's Analysis and Management Decision)

After we calculate the customers who order, we could calculate how many products they order in PT ABC. The price per order management decides Rp. 1,170, - with churn rate 26\%, then with management's assumption partners, the management estimates the growth of item per order is $110 \%$ in year two until year four and $80 \%$ in year five and year six, because the company had been agreed with many partners. The average markdown charge and giving discount or promo is $0.06 \%$.

\section{Assumption of Expense}

There are two types of expense in $\mathrm{PT} \mathrm{ABC}$, that are: marketing expenses, and general and administration (G\&A) expenses. the company also estimated expenses will be growing $75 \%$ in $2021,80 \%$ in 2023 , and $80 \%$ in 2025 . The data is collected by the author directly from management and the author does a discussion with management.

From the assumption above, we can conclude that management in PT ABC estimating the marketing expense (cost per click) is Rp. 548,84 per click. The management does not estimate the growth, because the price does still sustain in the same value for the last 12 months.

The company estimates that any growth in 2021, 2023, and 2025, because the operational needs to expand or it will develop a new project business. thus, the company needs a new human resource and employee's quality.

\section{Assumption of Current Asset and Current Liabilities}

\section{Current Assets}

The management of the company is estimated 180 of the account receivable days, and the company has office rent Rp. 2,799,291,866 with 12 months period while used 4 months. Then, the company also estimating rent will be growing $75 \%$ in 2021, 80\% in 2023, and $80 \%$ in 2025 . Copyright $\odot$ GLOBAL ACADEMIC EXCELLENCE (M) SDN BHD - All rights reserved 
With assumption, the company will move a building or rising expense. And the company does not have an inventory.

\section{Current Liabilities}

While current liabilities, the company estimated the fund will be liquified on 182 days or 2 days after account receivable earned. Because it refers to Otoritas Jasa Keuangan (OJK) policy about market exchange settlement period article 2 paragraph 2.

\section{Assumption of Capital expenditure and Financing}

\section{Capital Expenditure}

The company's Fixed assets will be increasing by $50 \%$ in 2022 and $75 \%$ in 2025 with the assumption that the company will be expanding its business every 2 years. And the company has not done any acquisition yet as long as five years. And management had to estimate the depreciation according to the type of fixed assets

\section{Financing}

In financing, the interest rate is according to the BI (Bank of Indonesia) rate published for loan investment. The rate is $10,02 \%$ in January 2020. Then, the company had a debt issue Rp. 1,421,435,059, - and invested Rp. 7,735,722,402, -

\section{Assumption of Valuation}

The valuation of the company has three items. The first item is the Tax rate, the tax rate is according to the percentage of income tax in Indonesian tax or $25 \%$. The second is the Discounted Rate, the discount rate could be calculated by weight average cost of capital (WACC). With detailed below:

Table 2: WACC Calculation

\begin{tabular}{lr} 
WACC & \\
Capital Structure & $86,82 \%$ \\
Debt to Total Capitalization & $13,18 \%$ \\
Equity to Total Capitalization & $658,90 \%$ \\
\hline Debt / Equity & \\
& \\
Cost of Equity & $7,48 \%$ \\
Risk-Free Rate & $7,08 \%$ \\
Equity Risk Premium & 0,48 \\
Levered Beta & $10,91 \%$ \\
\hline Cost of Equity & \\
& \\
Cost of Debt & $5,01 \%$ \\
Cost of Debt (before tax) & $25,00 \%$ \\
Tax Rate & $3,76 \%$ \\
\hline After-Tax Cost of Debt & $4,70 \%$ \\
\hline WACC
\end{tabular}

(Damodaratn, 2020) 
According to WACC Calculation above, the author gets debt to total capitalization (debt /equity + liability) $86,82 \%$ and equity to total capitalization $13,18 \%$ (Equity / equity + Liability). Then the cost of equity we can calculate using the risk-free rate on market bond data. The data stated $7.48 \%$ on March 13, 2020. And equity risk premium $(7.08 \%)$ can be used Damodaran's calculation updated period January 1, 2020.

Calculating beta is a bit more complicated case not - listed company, that is, a private company (Samonas, 2015). the management of the company decides to calculate based on beta from a similar company to find unleveraged beta then process according to the framework above. Thus, the unleveraged beta of the company earns 0.08 , and leverage beta is 0.48 .

The cost of equity result is $10.91 \%$. Calculating Cost of Debt is the cost of debt before tax or percentage of interest expense $(5.01 \%$ ) times $75 \%$ (1-tax rate). The result is $3.76 \%$. After calculating these items, we got $4.70 \%$ of WACC.

After calculating WACC, we can calculate terminal value exit multiple. It is pretty different to calculate the terminal value. The author compares the terminal value of comparable companies with EV/EBITDA. The result of the calculation is 31.92 times.

\section{Income Statement Projection}

Table 3: Income Statement Projection

\begin{tabular}{|c|c|c|c|c|c|c|c|}
\hline 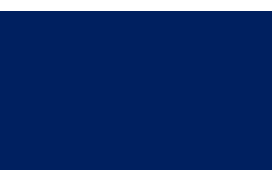 & $\begin{array}{r}\text { Startup } \\
\text { year } \\
2019\end{array}$ & 2020 & 2021 & 2022 & 2023 & 2024 & $\begin{array}{r}\text { Terminal } \\
\text { year } \\
\mathbf{2 0 2 5}\end{array}$ \\
\hline \multicolumn{8}{|c|}{ Income Statement (in million) } \\
\hline $\begin{array}{l}\text { Gross Revenue } \\
\text { Discounts, } \\
\text { Promotions, } \\
\text { Markdowns }\end{array}$ & 10.525 & $\begin{array}{r}151 \% \\
26.372\end{array}$ & $\begin{array}{r}151 \% \\
66.171\end{array}$ & $\begin{array}{r}151 \% \\
166.271\end{array}$ & $\begin{array}{r}152 \% \\
418.403\end{array}$ & $\begin{array}{r}116 \% \\
903.781\end{array}$ & $\begin{array}{r}116 \% \\
1.955 .146\end{array}$ \\
\hline Net Revenue & 10.513 & 26.341 & 66.095 & 166.080 & 417.922 & 902.742 & 1.952 .900 \\
\hline $\begin{array}{l}\text { Variable Ope } \\
\text { Marketing }\end{array}$ & $\begin{array}{c}\text { Expen } \\
89\end{array}$ & 107 & 129 & 156 & 189 & 229 & 278 \\
\hline $\begin{array}{l}\text { Total Variable } \\
\text { Costs }\end{array}$ & 89 & 107 & 129 & 156 & 189 & 229 & 278 \\
\hline $\begin{array}{l}\text { Contribution } \\
\text { Margin } \\
\text { Margin }\end{array}$ & $\begin{array}{r}\mathbf{1 0 . 4 2 3} \\
99,15 \%\end{array}$ & $\begin{array}{r}\mathbf{2 6 . 2 3 4} \\
99,59 \%\end{array}$ & $\begin{array}{r}\mathbf{6 5 . 9 6 6} \\
99,80 \%\end{array}$ & $\begin{array}{r}\mathbf{1 6 5 . 9 2 4} \\
99,91 \%\end{array}$ & $\begin{array}{r}\mathbf{4 1 7 . 7 3 3} \\
99,95 \%\end{array}$ & $\begin{array}{r}\mathbf{9 0 2 . 5 1 3} \\
99,97 \%\end{array}$ & $\begin{array}{r}\mathbf{1 . 9 5 2 . 6 2 3} \\
99,99 \%\end{array}$ \\
\hline $\begin{array}{l}\text { Fixed Operatin } \\
\text { Expenses } \\
\text { General \& } \\
\text { Administrative }\end{array}$ & 8.126 & 8.971 & 14.299 & 14.766 & 24.712 & 24.712 & 43.782 \\
\hline Total & 8.126 & 8.971 & 14.299 & 14.766 & 24.712 & 24.712 & 43.782 \\
\hline EBITDA & 2.297 & $\mathbf{1 7 . 2 6 3}$ & 51.667 & 151.159 & 393.021 & 877.802 & 1.908 .841 \\
\hline Margin & $21,9 \%$ & $65,5 \%$ & $78,2 \%$ & $91,0 \%$ & $94,0 \%$ & $97,2 \%$ & $97,7 \%$ \\
\hline Depreciation & 689 & 1.377 & 2.066 & 3.088 & 3.457 & 3.827 & 4.965 \\
\hline
\end{tabular}




\begin{tabular}{lccrrrrr} 
Interest & 71 & 142 & 142 & 142 & 142 & 142 & 142 \\
\hline $\begin{array}{l}\text { Earnings Before } \\
\text { Tax }\end{array}$ & 1.537 & 15.743 & 49.458 & 147.929 & 389.422 & 873.833 & 1.903 .733 \\
& & & & & & & \\
Taxes & 384 & 3.936 & 12.365 & 36.982 & 97.355 & 218.458 & 475.933 \\
\hline Net Income & $\mathbf{1 . 1 5 3}$ & $\mathbf{1 1 . 8 0 8}$ & $\mathbf{3 7 . 0 9 4}$ & $\mathbf{1 1 0 . 9 4 7}$ & $\mathbf{2 9 2 . 0 6 6}$ & $\mathbf{6 5 5 . 3 7 4}$ & $\mathbf{1 . 4 2 7 . 8 0 0}$ \\
\hline \hline
\end{tabular}

$\begin{array}{llllllll}\text { Dividends Paid } & 0 & 0 & 0 & 0 & 0 & 0 & 0\end{array}$

(Author's Analysis and Management Decision)

According to Income statement projections above, we can describe as follows:

1. In the actual year, the company earned net revenue Rp. 10,512,517,225 for one year. And will grow $151 \%-152 \%$ during the next 4 years and $116 \%$ in year five and six.

2. Variable operating expenses is Rp. $89,095,886$ and growing like revenue. Thus, the contribution margin is $99.15 \%$ on the actual year, and still stable in the next 5 years. And for fixed operating expenses is Rp 8,126,240,933 and the EBITDA margin is $21,9 \%$ actual years. For forecasting it will be fluctuating, the details could see in table 3.

3. After less all the expenses, the company will earn net income Rp. 1,152,936,280 in the current year and will fluctuate in the next 5 years. The details can see in table 3 above.

Table 4: Unlevered Free Cash Flow

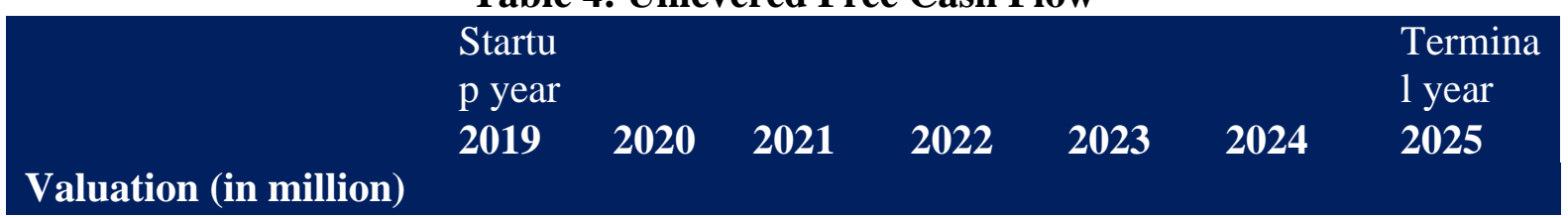

\section{Free Cash Flow}

\begin{tabular}{|c|c|c|c|c|c|c|c|}
\hline 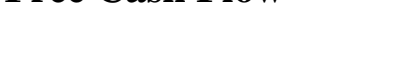 & & 15.74 & & 147.92 & 389.42 & & 1.903 .7 \\
\hline Earning Before Tax & 1.537 & 3 & 49.458 & 9 & 2 & 873.833 & 33 \\
\hline Interest & 71 & 142 & 142 & 142 & 142 & 142 & 142 \\
\hline & & 15.88 & & 148.07 & 389.56 & & 1.903 .8 \\
\hline EBIT & 1.608 & 6 & 49.601 & 1 & 4 & 873.975 & 76 \\
\hline & & $(3.97$ & $(12.40$ & $(37.01$ & $(97.39$ & $(218.49$ & $(475.96$ \\
\hline Less Taxes & $(402)$ & 1) & 0) & 8) & 1) & 4) & 9) \\
\hline & $(2.819$ & $(2.81$ & $(2.819$ & $(4.228$ & $(4.228$ & & \\
\hline Less Capex & ) & 9) & ) & ) & ) & $(4.228)$ & (7.399) \\
\hline Plus Depreciation & 689 & 1.377 & 2.066 & 3.088 & 3.457 & 3.827 & 4.965 \\
\hline Less Changes & $(1.720$ & & & & & & \\
\hline Working Capital & ) & 931 & 218 & 315 & 1.380 & 2.657 & 5.171 \\
\hline Unlevered Free Cash & $(2.643$ & 11.40 & & 110.22 & 292.78 & & 1.430 .6 \\
\hline Flow & ) & 5 & 36.666 & 8 & 2 & 657.737 & 44 \\
\hline
\end{tabular}

Based on the data above, we can conclude that the company has minus unlevered Free cash flow in the actual year (2009) because it still develops the business. but in the next 5 years, unlevered free cash flow will be rapidly growing. 
Table 5: DCF Valuation

DCF Valuation

\begin{tabular}{lll}
$\begin{array}{l}\text { NPV of Forecast } \\
\text { Terminal Value (EBITDA } \\
\text { multiple) }\end{array}$ & $4,70 \%$ & 1.900 .866 .956 .035 \\
$\begin{array}{l}\text { NPV of Terminal Value } \\
\text { Total Enterprise Value }\end{array}$ & $31,9 x$ & 60.938 .615 .394 .745 \\
\cline { 2 - 2 } $\begin{array}{l}\text { EV/Revenue (2020E) } \\
\begin{array}{l}\text { \% of Business Retained } \\
\text { after raise }\end{array}\end{array}$ & $\mathbf{4 6 . 0 8 4 . 7 3 5 . 4 0 3 . 7 4 2}$ \\
& $\mathbf{1 7 4 8 x}$ \\
& $\mathbf{1 0 0 , 0 \%}$
\end{tabular}

(Author's Analysis and Management Decision)

Then based on unlevered free cash flow above, we can calculate the valuation of the company using the DCF method. The data shows that The NPV of the forecast with a discounted rate of $4.7 \%$ is Rp. 1,900,866,956,035 and terminal value with 31.9 time is Rp. 60,938,615,394,745 resulting Rp. 44,183,868,447,707 of The NPV of Terminal Value. The enterprise value is Rp. $46,084,735,403,742$. Then, EV/Revenue is 1,748 times and percentage of raise is $100 \%$

\section{Conclusion and Recommendation}

\section{Conclusion}

The company is rapidly growing, it is proven by the data showing that the enterprise value is Rp. 46,084,735,403,742. Then, EV/Revenue is 1,748 times, and the percentage of business retained after raise is $100 \%$. the growth of costumers based on google analytics is pretty goods. The churn rate has $26 \%$. It is implicating that the company still has many loyal customers. After discussing with the head of finance and accounting PT ABC, the management decides to sell a maximum of $25 \%$ of the ownership or Rp. 11,521,183,850,935.5, -

\section{Recommendation}

The research is using Discounted Cash Flow with sensitivity analysis, so it is recommended for further research to use other methods such as real options method, book value method, etc. so that many investors consider investing in PT ABC.

The company should do many collaborations with other institutions for growing its performance especially in revenue. If the revenue growing rapidly, it will automatically make a perfect valuation. Thus, the company will be easy to be a unicorn startup.

According to DCF Valuation, the author suggests investors invest in the company. Because the valuation is very good. We can see on the data showing for one year established, the company could be giving Rp. 46,084,735,403,742 of the valuation.

\section{References}

Achleitner, A. (2018). Start-up Unternehmen. Springer Gabler Verlag, pp. http://wirtschaftslexikon.gabler.de/Archiv/427/start-up-unternehmen-v7.html. .

Bell, B. G. (2014). Angel investor sophistication: Increasing application of pre-revenue venture valuation methodologies. The Journal of Private Equity, 8.

Blake, M. (2016). Valuing Early Stage Technology Firms. Advances in the Study of Entrepreneurship, Innovation, and Economic Growth, 311-340. 
Blank, S. \&. (2012). The Startup Owner's Manual, The Step-by-Step. In S. \&. Blank, The Startup Owner's Manual, The Step-by-Step (p. www.steveblank.com). California: K and $\mathrm{S}$ Ranch Inc.

Brigham, E. F. (2004). Intermediate Financial Management (8 ed.). United States, United States.

Brotherson, W. T. (2014). Company valuation in mergers and acquisitions. how is discounted cash flow applied by leading practitioners?, 24(2), 43-51.

Corporate Finance Institute. (2020). Exit Multiple. What is Exit Multiple?, pp. https://corporatefinanceinstitute.com/resources/knowledge/finance/exit-multiple/.

Corporate Finance Institute. (2020). WACC. https://corporatefinanceinstitute.com/resources/knowledge/finance/what-is-waccformula/.

Curry, J. X. (2018). To sell or not to sell? A case on business valuation. Journal of the International Academy for Case Studies, 1-9.

Damodaran, A. (2011). Applied Corporate Finance. New York: Wiley.

Damodaratn, A. (2020). Equity Risk Premium. United Sates: New York University.

Divestopedia. (2016, April 2016). Valuation. Valuation Methods, p. https://www.divestopedia.com/definition/993/valuation.

Djaja, I. (2017). All About Corporate Valuation. In I. Djaja, All About Corporate Valuation (pp. 38, 101, 90-92). Jakarta, DKI Jakarta, Indonesia: PT Alex Media Komputindo.

Imam, S. B. (2008). The Use of Valuation Models by UK investment Analyst. European Accounting Review

International FInancial Standard. (2013). Fair Value Measurement. London: IFRS.

Ivanovska, N. I. (2014). Fundamental analysis and discounted free cash flow valuation of stocks at macedonian stock exchange. 5(1), 11-24.

Lopez, F. J. (2008). Valuation of small business: An alternative point of view. Journal of Business valuation and Economic loss analysis, 1-66.

Mardalis. (2010). Metode Penelitian. Jakarta: Bumi Aksara.

Pohl, P. (2017). Valuation of a Company Using Time Series Analysis. Journal of Business Valuation and Economic Loss Analysis, 1(12), 1-39.

Ries, E. (2011). The Lean Startup. Jakarta: Penerbit Bentang.

Robehmed, N. (2013, December 16). What is A Startup?

Samonas, M. (2015). Financial Forecasting, Analysis, and Modelling. Cornwall: Wiley.

Sekaran, U. \&. (2010). Research Methods for Business (A skill building approach). United Kingdome: John Wiley \& Sons Ltd.

Zaky, M. A. (2018). Mapping \& Database Startup Indonesia. Jakarta, Indonesia: Masyarakat Industri Kreatif Teknologi Informasi. 